\title{
An Intertextual Reading Intervention Program to Improve Reading Motivation of College Students
}

\author{
Joderic C. Navarrete
}

\author{
Leyte Normal University, Tacloban City, Philippines; joenavsatlnu@gmail.com
}

\begin{abstract}
Objectives: Reading motivation remains a gap in literacy instruction, even at the tertiary level. This study is conducted to investigate if the Intertextual Reading Intervention (IRI) program could improve the reading motivation of first-year tertiary education students at Leyte Normal University. Methods: Fifty respondents were subjected to a one-semester intervention program which was conducted at the computer laboratory of the university. Reading survey was administered as pretest and posttest. Importantly, five intertextual modules were developed and used during the intervention. Findings: This study revealed that students' reading motivation improved significantly as shown in the overall reading survey result: Posttest result $(\mathrm{M}=81.6, \mathrm{SD}=6.5)$; pretest $(\mathrm{M}=76.8, \mathrm{SD}=6.9), \mathrm{t}(37)=4.97, \mathrm{p}=<.001$. This indicates that the utilization of intertextual materials particularly media texts or Internet resources and technology (e.g. computer laboratory) could improve students'motivation to read. Applications/Improvements: Tertiary education demands reading various academic texts, both printed and digital media and most of these texts are long and not student-friendly, which means, concepts are complicated and heavy. Hence, educators could use intertextual materials which are relative to their students' schemata, interest and have life-long implications to motivate their students to read. Further, the discouraging feeling of handling students who have very low motivation to read level could be lessened with the use of possible instructional reforms (e.g. intertextual strategies).
\end{abstract}

Keywords: Intertextuality, Intervention Program, One-group Pretest-posttest Design, Reading Motivation

\section{Introduction}

Motivation could be defined as a cause that moves a person to act on something (e.g. to read) in order to fulfill a need ${ }^{1,2}$. Many researchers agreed that motivation is an indispensable factor of the reading act $^{3-5}$. For example, ${ }^{6}$ found that motivation influences students' performance. In the same vein, ${ }^{7}$ proved that motivation is fundamental in improving reading comprehension. Moreover, ${ }^{8}$ indicated that learner's motivational level is one of the factors that give currency to academic performance, especially at the tertiary level ${ }^{9}$. Studies revealed several constructs or dimensions that could affect reading motivation ${ }^{10}$, for example, self-concept and value of reading ${ }^{11,12}$.

\subsection{Self-concept}

Self-concept refers to the interconnection of several components: Competence, perception and attitude. Hence, a person with a good self-concept about reading apparently becomes a proficient reader which is somehow correlated to reading performance.

For example, a learner who can read a page thinks he/she can read the next page and the next and in time, the entire book. Further, some educators considered self-concept as a criterion in assessing their learners' performance in a particular educational task (e.g. reading a book) ${ }^{13}$.

\subsection{Value of Reading}

Value of reading is associated with having an awareness that reading is important. $\mathrm{In}^{3}$ stressed that at the heart of motivation to read is believing in its value, for instance, reading helps a person improve his or her reading skills and it is important for the future like finding work, etc. The success or failure of an individual is anchored on how much value he/she allocates to a certain task. Thus, a person who gives importance to reading will exert more effort to this task. Importantly, giving value to reading is correlated to engagement, sense of competence and students' achievement ${ }^{14}$. 


\subsection{Literacy Gap in Higher Education}

Extensive research has shown that many college students are not prepared for tertiary work ${ }^{15}$. Consequently, admittance and retention continue to become a challenge in various colleges and universities. Tertiary education demands reading various academic texts, both printed and digital media and most of these texts are long and not student-friendly. This means that the concepts are generally complicated and heavy, especially if a student lack background knowledge and experience/s on the topic ${ }^{16}$. Further, these texts require deeper understanding and critical reading skills like comparing and contrasting, integrating current texts to past texts and multiple texts comprehension ${ }^{17}$. Aside from poor learners' reading comprehension specifically in higher order thinking skills, this problem could also be attributed to the insufficiency of mentors in terms of knowledge in instructional pedagogies, like some teachers use only one textbook in teaching a subject or course content. This is exacerbated by the fact that students often considered learning as a static process comparable to hearing someone without the intention of processing deeply the information received. Subsequently, these students will not be motivated to read.

Studies have shown that reading motivation is at the center of various problems teachers are facing in educating students ${ }^{18,19}$. In fact, it is a gap in reading instruction that needs to be addressed, aside from reading comprehension. $\operatorname{In}^{20}$ emphasized that very little is known about reading motivation.

\section{Theoretical Framework}

This study is anchored on the theory of intertextuality. Julia Kristeva, a French linguist, christened and first used the term intertextuality ${ }^{21}$. However, her idea was not novel and innovative; it was clearly anchored on the work of Mikhail Bakhtin's dialogism which postulates that there is a continual dialogue among texts. $\operatorname{In}^{9}$ emphasized that to have intertextuality during classroom instruction, educators should use a variety of printed and nonprinted materials like media songs, cultural experiences and events. Other scholars recommended trade books, e-books, graphic organizers, and drawing ${ }^{22}$. These specific features of intertextuality were integrated into the development of the modules.

\section{The Purpose of the Study}

The study was conducted to examine whether the IRI program could improve students' reading motivation in the following motivational constructs: Self-concept and value of reading.

\section{Methodology}

\subsection{Research Design}

The study employed an experimental design particularly the one-group pretest-posttest design ${ }^{23}$.

\subsection{Respondents of the Study}

Fifty students were randomly selected as respondents of the study ${ }^{24}$. The intervention was done in a computer laboratory of the school, which could accommodate up to 50 students. Importantly, informed consent and anonymity of students were strictly considered.

\subsection{Research Procedure}

The researcher sought permission from the officials of the university to conduct the intervention program and the use of the computer laboratory. Afterwhich, respondents were identified and asked to request their parents to sign a waiver, allowing them to participate in the intervention. Then the pretest was administered, and the conduct of the intervention program commenced. It was done for three hours once a week and lasted for five months. Posttest was administered after the intervention.

\subsection{The Instruments}

The following are the instruments used in the study:

\subsubsection{Motivation to Read Profile (MRP): Reading} Survey

This was used to measure students' self-concept and value of reading ${ }^{25,26}$. This instrument has three parts: The first tackles narrative text (three questions), the second is on informational reading (three questions) and the third is about general factors related to reading motivation (eight questions). This survey consists of 20 items and is a 4-point response scale to avoid neutral, central response pattern. Respondents were asked to shade a particular option which best describes themselves. Though the test 
is good for 20 minutes, respondents were given ample time to finish answering the test. This was administered as pretest and posttest.

\subsubsection{Intertextual Modules}

Intertextual modules were utilized during the conduct of the intervention. The selection of materials and topics were anchored on the schemata of the students. Majority of the materials were taken from college textbooks, Internet sources and pop culture media texts such as songs, documentary films, etc. After the first draft of the five modules was written, these were given to experts for critiquing and validation. Secondary and tertiary reading and language teachers composed the panel of experts. Pilot testing was done to test the validity of the modules.

\subsection{Statistical Analysis}

The survey was used to determine the students' reading motivational level. However, some students dropped out in the program; instead of 50 only 37 participants were included in the data analysis. The pre-posttest results were computed for each motivational construct or dimension using the MRP Reading Survey Scoring Sheet. The researcher employed descriptive statistics to analyze the data.In addition, inferential statistics, specifically paired t-test, was also used.

\section{Results and Discussion}

The results of the two motivational constructs and the overall reading survey are discussed in this section.

\subsection{Respondents' Self-concept}

One of the motivational constructs assessed in this study is self-concept. Table 1 reflects the results of these two constructs or dimensions.
Data from the above table indicates a significant difference in respondents' self-concept as shown in their posttest scores $(\mathrm{M}=77.7, \mathrm{SD}=7.7)$ as compared to their pretest score $(\mathrm{M}=73.3, \mathrm{SD}=8.0), \mathrm{t}(37)=3.70, \mathrm{p}=.001$. This positive result might be accredited to the utilization of various engaging activities (e.g., group activities, drawing, class sharing of interpretations/perspectives). $\operatorname{In}^{27}$ found that using engaging activities, not only capture students' interest but promote self-concept, as well. Further, the IRI program also asked the respondents to accomplish graphic organizers; for instance, during vocabulary development (specifically before reading/ engaging an intertextual text. $\mathrm{In}^{11}$ found the use of graphic organizers to be effective in boosting readers' self-concept. Similarly, ${ }^{28}$ proved that reading self-concept is positively correlated to reading performance. On the other hand, emphasized that low self-concept is one of the factors which caused reading comprehension difficulties.

\subsection{Students' Value of Reading}

Respondents' value of reading also shows a significant difference as reflected in their posttest scores $(\mathrm{M}=85.5, \mathrm{SD}=7.4)$ as compared to their pretest score $(\mathrm{M}=80.9, \mathrm{SD}=8.4), \mathrm{t}(37)$ $=3.71, \mathrm{p}=.001$. This result could suggest that respondents considered reading as an important tool, which would help them become successful in school and in life. It is a fact that the success or failure of an individual is dependent on how much value he/she allocates to a certain task, for instance, a person who gives importance or value to reading will exert more effort on this task. Therefore, valuing reading is associated with engagement and achievement. $\operatorname{In}^{14}$ found that students who value reading were able to develop mastery in the use of the English language.

\subsection{The Full Survey}

Subsequently, the full survey posttest result $(\mathrm{M}=81.6, \mathrm{SD}$ $=6.5)$ indicates a significant difference over the pretest $(\mathrm{M}$ $=76.8, \mathrm{SD}=6.9), \mathrm{t}(37)=4.97, \mathrm{p}=<.001$.

Table 1. Mean percent score on dimensions of reading motivation

\begin{tabular}{|c|c|c|c|c|c|c|}
\hline \multirow{2}{*}{ Dimensions of Reading Motivation } & \multicolumn{2}{|c|}{ Pretest Score } & \multicolumn{2}{|c|}{ Posttest Score } & \multirow{2}{*}{ t-value } & \multirow{2}{*}{$\mathrm{p}$-value } \\
\hline & Mean & SD & Mean & SD & & \\
\hline Self-concept as Reader & 73.3 & 8.0 & 77.7 & 7.7 & 3.70 & .001 \\
\hline Value of Reading & 80.9 & 8.4 & 85.5 & 7.4 & 3.71 & .001 \\
\hline Full Survey & 76.8 & 6.9 & 81.6 & 6.5 & 4.97 & $<.001$ \\
\hline $\mathrm{N}=37, \alpha=0.01$ & & & & & & \\
\hline
\end{tabular}


This overall result could be associated (in addition to what were mentioned earlier) with the use of intertextual pedagogy and a variety of materials. These materials were relative to students' schemata. Data from several studies suggest the importance of students' schemata in reading instruction ${ }^{30}$, especially reading materials that foster a personal connection to students' everyday lives and have lifelong value. Moreover, the use of various types of resources like media texts or Internet resources (e.g. songs, video clips, movies, etc. ${ }^{31}$ and technology (e.g. computer laboratory and LCD projector ${ }^{32,33}$ could enhance motivation to read, especially for low performing students.

\section{Conclusion}

The results of the current study pose a contrasting view against a myriad of studies which centered primarily on reading comprehension. Moreover, tertiary level demands reading various academic texts which contain concepts that are complicated. Hence, educators could use intertextual strategies and materials in classroom instruction which are relative to their students' schemata, interest and have life-long implications. Further, the discouraging feeling of handling students who have very low motivation to read level could be lessened through the utilization of possible instructional reforms, especially the use of technology and Internet resources. Moreover, this paper is the first to examine reading motivation and intertextuality as used in an intervention program for low performing tertiary students. Further research is needed to confirm these results and to examine these in more depth.

\section{References}

1. Goodman T, Keresztesi M, Mamdani F, Mokgatle D, Musariri M. An investigation of the relationship between students motivation and academic performance as mediated by effort. South African Journal of Psychology. 2011; 41(3):373-85. https://doi.org/10.1177/008124631104100311

2. Motivation: A Literature Review. 2011. https://images. pearsonassessments.com/images/tmrs/Motivation_ Review_final.pdf

3. Motivating and engaging students in reading. 2010. https:// www.academia.edu/2265143/Motivating_and_engaging_ students_in_reading

4. McLaughlin M. Reading comprehension: What every teacher needs to know. The Reading Teacher. 2012; 65(7):432-40. https://doi.org/10.1002/TRTR.01064
5. SturtevantEG, Kim GS. Literacy motivation and school/nonschool literacies among students enrolled in a middle-school ESOL program. Literacy Research and Instruction. 2010; 49(1):68-85. https://doi.org/10.1080/19388070802716907

6. Guthrie JT, Wigfield A. Roles of motivation and engagement in reading comprehension assessment. Children's Reading Comprehension and Assessment; 2005. p. 187-214.

7. Guided reading, fluency, accuracy and comprehension. 2010. https://minds.wisconsin.edu/handle/1793/53230

8. Fraser W, Killen R. The perceptions of students and lecturers of factors influencing academic performance at two South African universities. Perspectives in Education. 2005; 23:25-40.

9. Armstrong SL, Newman M. Intertextuality in college reading classroom. Journal of College Reading and Learning. 2011; 41(2):6-21. https://doi.org/10.1080/10790195.2011.10850339

10. Navarrete J. IRI Program: Its effect on reading attitude of low performing freshmen education students. International Journal of Education and Research. 2018; 6(10):47-56.

11. Guthrie JT, Klauda SL, Ho AN. Modeling the relationship among reading instruction, motivation, engagement and achievement for adolescents. Reading Research Quarterly. 2013; 48(1): 9-26. https://doi.org/10.1002/rrq.035

12. What is the value in reading?2015. https://www.quora.com/ What-is-the-value-in-reading

13. Adaptation of the motivation to read profile to Turkish. 2013. https://www.researchgate.net/publication/272877397_ Adaptation_of_the_motivation_to_read_profile_to_Turkish

14. Protacio MS. Reading motivation: A focus on English learners. The Reading Teacher. 2012; 66(1):69-77. https:// doi.org/10.1002/TRTR.01092

15. When reforms don't transform: Reflections on institutional reforms in the Department of Education. 2010. https:// www.researchgate.net/publication/237259856_When_ Reforms_Don't_Transform_Reflections_on_institutional_ reforms_in_the_Department_of_Education

16. Wilkinson IA, Son EH. A dialogic turn in research on learning and teaching to comprehend. Handbook of Reading Research; 2011. p. 359-87.

17. Braten I, Britt MA, Strømsø HI, Rouet J. The role of epistemic beliefs in the comprehension of multiple expository texts: Toward an integrated model. Educational Psychologist. 2011; 46(1):48-70. https://doi.org/10.1080/0 0461520.2011 .538647

18. Edmunds KM, Tancock, SM. Incentives: The effects on the reading motivation of fourth-grade students. Reading Research and Instruction. 2003; 42(2):17-37. https://doi.org/10.1080/19388070309558384

19. Uygulamada K, Bilimleri E. The motivational factors for reading in terms of students. Educational Sciences: Theory and Practice. 2011; 11(2):954-60. 
20. Kim KJ. Reading motivation in two languages: An examination of EFL college students in Korea. Reading and Writing: An Interdisciplinary. 2011; 24(8):861-81. https:// doi.org/10.1007/s11145-010-9229-Z

21. Word, Dialogue and Novel. 1980. https://cpb-us-w2. wpmucdn.com/u.osu.edu/dist/3/29382/files/2016/03/ Kristeva-Word-Dialogue-and-Novel-2kauf14.pdf

22. Cobb JB. It's me. I'm fixin to know the hard words: Children's perceptions of "good readers" as portrayed in their representational drawings. Journal of Research in Childhood Education. 2012; 26:221-36. https://doi.org/10.1080/0256 8543.2012.657746

23. Rajlamal A, Prema N. Effectiveness of counseling on emotional intelligence of school students. Indian Journal of Science Teaching. 2019; 12(11):1-7. https://doi. org/10.17485/ijst/2019/v12i11/138212

24. Sampling Techniques. 2018. https://towardsdatascience. com/sampling-techniques-a4e34111d808

25. Gambrell LB, Palmer BM, Codling RM, Mazzoni SA. Assessing reading motivation. The Reading Teacher.1996; 49:518-33. https://doi.org/10.1598/RT.49.7.2

26. Assessing motivation to read. 2014. http://www.booktrust. org/files/2016/08/Motivation-to-Read-Profile-Revised.pdf
27. Content area literacy: Learners in context. 2012. https:// www.pearson.com/us/higher-education/program/ConleyContent-Area-Literacy-Learners-in-Context-2nd-Edition/ PGM97019.html

28. Chapman JW, Tunmer WE. A longitudinal study of beginning Reading achievement and reading self-concept. British Journal of Educational Psychology. 1997; 67:279-91. https://doi.org/10.1111/j.2044-8279.1997.tb01244.x

29. Reading comprehension: Assisting children with learning difficulties. 2011. https://www.springer.com/in/ book/9789400711730

30. Building a culture of engaged academicliteracy in schools. 2014. https://www.literacyworldwide.org/docs/defaultsource/member-benefits/e-ssentials/ila-e-ssentials-8066.pdf

31. Pelekis K. How a Geography Wiki led to enthusiastic learning? Reading Today. 2011;29(1): 1-10.

32. Toppel K. Enhancing core reading programs with culturally responsive practices. The Reading Teacher. 2015; 68(7):552-9. https://doi.org/10.1002/trtr.1348

33. Steckel B, Shinas VH, Vaerenewyck LV. Artistic technology integration: Stories from primary and elementary classrooms. The Reading Teacher. 2015; 69(1):41-9. https://doi. org/10.1002/trtr.1356 